\section{Elections and CEO successions in Brazilian state-owned companies}

\author{
Sergio Foldes Guimaráes ${ }^{1}$ \\ André Luiz Carvalhal da Silva ${ }^{1}$ \\ ${ }^{1}$ Federal University of Rio de Janeiro, Coppead Institute \\ of Administration, Rio de Janeiro, Brazil
}

\begin{abstract}
Purpose - To study the impacts of elections and succession processes on SOE stocks.

Design/methodology/approach - Through events studies we longitudinally investigate the impacts of political events (elections) and of succession processes on SOE stocks over more than 20 years. We also document changes in management, showing that SOEs face greater turnover in management than their private peers. Stock quotations were obtained from Economática and company and executive data were retrieved from the B3 and CVM.
\end{abstract}

Findings - There is some but not a general impact of elections and succession processes on SOEs. More recently, the impacts have increased. CEO turnover is greater in SOEs than in their private peers and changes in management are greater in cases of power shifts.

Originality/value - We shed light on phenomena that happen frequently in Brazil: CEO successions in SOEs and political events impacting SOEs.

Keywords - state-owned companies, CEO succession, corporate governance and ownership structure
462

Received on

07/31/2018

Approved on

$06 / 28 / 2019$

Responsible editor:

Prof. Dr. Joelson Oliveira

Sampaio

\section{Evaluation process:}

Double Blind Review

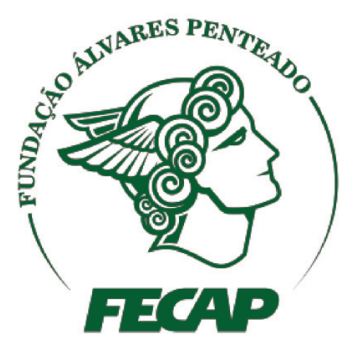

Revista Brasileira de Gestáo de Negócios

DOI: $10.7819 /$ rbgn.v22i0.4060 


\section{Introduction}

This study investigates how elections and executive turnover affects state-owned enterprises (SOEs), an important part of the Brazilian economy. In the past two decades, discussions about the governance and strategic importance of these companies have been in the headlines, swinging between those who desire privatization and defendants of a greater role of SOEs in the economy. Concerns about governance in SOEs has been a theme of political discussions and debate in Brazilian society, as they have often been involved in corruption scandals and faced management and governance problems caused by political interference.

Recent changes in the law try to minimize these problems but the real impacts are yet to be seen. However, initial tests provide evidence that political interference may not have finished. A recent case of CEO (Chief Executive Officer) succession in the most important Brazilian SOE (Petrobras) shows that political interference can still have an impact on markets and be a determinant of executive turnover in SOEs.

CEO succession has been a key theme for researchers but not specifically regarding SOEs, despite their presence being relevant in several economies. We posit that successions in SOEs are linked to political and electoral processes, with executive turnover in SOEs being greater than in private companies, making succession and governance processes in SOEs unique.

In general, there is a downward trend in CEO tenures, which Charan (2005) calls the "CEO crisis," this being more dramatic in companies without successors ready to take the helm. Shorter CEO tenures provoke corporate instability and market uncertainty, which may harm a company's image and affect all stakeholders. It is in this context that succession matters more than ever.

A recent survey (http://reports.weforum. org/outlook-global-agenda-2015/top-10-trendsof-2015/3-lack-of-leadership, retrieved on
September $\left.20^{\text {th }}, 2019\right)$ mentions lack of leadership as being a global trend, as $86 \%$ of the respondents think there is a leadership crisis. Brazil has one of the lowest rates of confidence regarding leadership.

In democracies, politicians must face elections every few years and in companies, CEOs must be confirmed by shareholders and boards and are threatened by the possibility of being ousted. In fact, as well as during the election or general assembly period, there is always the chance of an unexpected turnover.

CEOs of listed SOEs are often seen as executives and politicians, as they are appointed by governments and are subject to double pressure, from the government and market participants.

The political praxis in Brazil, now unveiled by “Operation Car Wash," has been to let different political parties forming a coalition appoint individuals to top positions in Brazilian SOEs. This often leads to corruption scandals. The President of Brazil, as the head of the executive power, can appoint 22,500 people to public positions, far more than the 4,000 in the US, 300 in the UK, and 500 in France and Germany, according to Claudio Abramo, from the nongovernmental organization Transparência Brasil.

Brazilian SOEs are historically among the most important listed companies on the B3 (the Brazilian stock exchange). This paper will focus on succession processes at the SOEs in Brazil listed on the $\mathrm{B} 3$ and forming part of the IBOVESPA benchmark index: Banco do Brasil (BB), Eletrobras, and Petrobras.

We will analyze, through a longitudinal study spanning more than two decades, the impact of elections and successions on the market value of those companies. During this time span, at least once, all three companies had losses attributed to mismanagement and political use to promote unsustainable policies favored by different governments.

Thus, analyzing SOE performance linked to CEO appointments is relevant for understanding how perceptions of political influence drive market reactions. 
Brogaard and Detzel (2015) showed how uncertainty related to government economic policies affects the decision-making processes of investors and companies in general, and how it is an important risk factor. Election periods are prone to increased uncertainty and the outcomes of polarized elections can have dramatic impacts on markets. Białkowski, Gottschalk, and Wisniewski (2006) highlighted that elections processes in 27 OECD countries do promote market volatility.

Besides market volatility and uncertainty related to government economic policies, elections affect SOEs directly, as changes in top management are dependent on the political process, potentially affecting their strategy.

Several conflicts of interest may arise in SOEs, which are seen as hybrid organizations (Bruton, Peng, Ahlstrom, Stan, \& Xu, 2014), as they play additional roles given by government, while shareholders complain that management does not seek value maximization. Carvalho (2014) shows how governments can shape public policies and use SOEs to implement them, favoring political allies in elections.

The relationship between succession and performance in SOEs presents additional challenges, as the life cycle of main executives is subject to the political cycle, where changes in the balance of power in government affect the top management of those companies. Thus, the relevance of succession in SOEs is paramount but not fully understood.

Management turnover and $\mathrm{CEO}$ succession in SOEs is different from in their private counterparts and linked to the political process. To gather evidence of this phenomenon, we investigated yearly changes in management in official documents filed at the CVM, paying special attention to changes after election years.

By analyzing those changes in top management disclosed in official documents, we found that CEO turnover in SOEs is greater than in private companies and can be linked to the political cycle, which makes it important to analyze the impacts of elections and CEO turnover on market performance.

After the recent corruption scandals involving SOEs such as Eletrobras and Petrobras and several private groups in Brazil, linked with corruption among politically appointed executives, Congress approved law 13,303/2016, strengthening governance requirements, improving transparency, disclosure, risk management, and compliance aspects in SOEs, and giving special attention to executive and board member appointment processes. The law is quite recent but is already being questioned by congressmen that want to soften its requirements.

Event studies on political events (presidential elections and impeachment processes) and CEO successions in SOEs show that, in several cases, the SOE's market performance was affected and there is evidence of abnormal returns (AR) on the day of the event or cumulative abnormal returns (CAR) around the day of the event.

To the best of our knowledge, this is the first study to combine an analysis of changes in top management in documents filed by companies at the CVM with quantitative results from shorthorizon event studies, providing a unique insight into phenomena that should be studied more: the impacts of CEO succession and political processes on market prices.

The structure of this paper proceeds along the following lines: Section 2 provides a literature review on succession, in Section 3 we present the data and methodology, Section 4 discusses the results, and Section 5 concludes the paper.

\section{Literature Review}

Research on CEO succession has attracted many scholars, looking at succession events through different lenses: human resources, planning, strategy, leadership, and finance. The antecedents and consequences of succession, including firm and CEO characteristics, were reviewed by Giambatista, Rowe, and Riaz (2005).

The research also seeks to identify the key ingredients for success in successions and 
the role of executives in leading companies and driving firm performance. A key variable is the origin of the newly appointed CEO, as insiders (working within the company) and outsiders may face different difficulties but can bring different contributions to the firm.

The relationship between CEO origin and firm performance is one of the most important streams of research. Zhang and Rajagopalan (2010) look at succession processes, focusing on how firm performance and changes in strategy vary according to CEO origin. Jalal and Prezas (2012) examine outsider CEO succession and its relationship with firm performance, finding that insider succession provides better immediate results, but outsiders display better stock performance in later years. Ferris, Jayeraman, and Jongha (2015) summarize sixty years of research on the origin of successors and capital allocation decisions regarding dividends, M\&A, and investments.

The industry is another important variable when studying CEO succession processes. Industry-related aspects of succession were analyzed by Datta and Rajagopalan (1998). Often, the definition of insider has incorporated industry-specific as well as company-specific knowledge.

Berns and Klarner (2017) published a comprehensive literature review on CEO succession, trying to understand successions in companies as complex processes rather than isolated events when companies have succession planning.

CEO turnover may happen for different reasons. It can be voluntary or forced, planned or unexpected, with different consequences for companies. How each process unfolds may depend on case-specific agency problems between executives and shareholders, according to Jensen and Meckling's (1976) theory of the firm, making it important to understand how shareholders monitor and control companies.

Guo and Masulis (2015) provide evidence of how differences in board structure and monitoring have an impact on CEO turnover. Greater board independence leads to more rigorous $\mathrm{CEO}$ monitoring.

The relationship between CEO succession and firm performance has been studied by many scholars. Jenter and Kanaan (2015) showed that CEOs may be dismissed due to factors outside their control and Huson, Malatesta, and Parrino (2004) analyzed the impact of successions on firm performance, finding that performance usually declines prior to successions, only to improve afterwards, both through accounting measures and market performance.

CEO successions are often related to poor performance or crises. Gangloff, Connely, and Shook (2014) studied investor reactions to executive succession in companies that have run into problems of financial misrepresentation, showing that signaling change or scapegoating are successful strategies to overcome them.

Connelly, Ketchen, Gangloff, and Shook (2016) analyze market reactions to new CEOs when companies present integrity or competence failures, finding that a common strategy is to communicate that the problem is gone after the former CEO leaves to restore investor confidence and that the type of successor the firm chooses is a critical aspect of successful communication.

Shen and Cannella (2003) show that succession is a common concern for investors, with succession planning being part of the strategic discussion within companies. Investors react favorably when the heir apparent is nominated as the new CEO in high performance companies.

Most of the research on succession focuses on developed markets and companies with a wide ownership. The typical agency conflict studied is between shareholders and executives, although it is noted that in companies with relevant shareholders that exert considerable influence on management, conflicts between controlling and minority shareholders are common.

This last type of conflict prevails in emerging markets, where companies do not 
usually have a wide ownership but instead have strong controlling groups. This is precisely the case of SOEs in emerging and transition economies, where governments appoint the management of SOEs and often favor the execution of public policies rather than efficiency or financial performance.

Crossland and Hambrick (2011) analyzed the differences in country-level institutions in 15 OECD countries, showing that managerial discretion varies across countries and institutions, which may limit CEOs in promoting change. According to Crossland and Chen (2009), executive accountability varies across countries, implying different relationships between performance and CEO dismissals.

Another understudied question is the role of SOEs in different economies. Christiansen (2011) points out that there are 48 listed SOEs in OECD countries, with a market value of over US\$ 500 billion. The OECD Guidelines on Corporate Governance of State-Owned Enterprises, last updated in 2015, helps understand the challenges of SOEs, which vary in different countries.

In emerging and transition economies, SOEs have greater presence and importance. Andres, Guasch, and Azumendi (2011) looked at governance characteristics in energy and water SOEs in Latin American and found that good governance and regulation are key to mitigating minority shareholder expropriation by controlling shareholders.

Conflicts of interest in SOEs in emerging economies are a special case of the governance and agency conflicts that affect companies in general in non-OECD markets, as control value is often much higher than market value. Few dedicated studies cover succession in those different market environments.

Lazzarini and Musacchio (2015) try to gauge the "CEO effect" in Brazilian SOEs, looking at a dataset of SOEs covering the 1970s to the 1990s. They arrive at the conclusion that a $2 \%$ increase in the return on assets can be attributed to a specific CEO, by following CEOs that have taken this position at more than one SOE. They point out that turnover in SOEs is much greater than in private companies and that spurious effects may affect their analysis. It is hard to compare with SOEs nowadays, after the wave of privatization in the 1990s.

Succession in SOEs has attracted a few studies. Chang and Wong (2009) covered executive turnover in China and its relationship with the multiple objectives of governance in SOEs, highlighting that there is scarce research on the monitoring of managers but there is a direct relationship between managerial turnover, firm financial performance, and those multiple objectives.

$\mathrm{Yu}$ and Lee (2016) analyzed SOE performance in Korea in relation to the financial crisis, linking performance with the political connectedness of CEOs, and showing that biographical information and political relationships are important factors for CEOs in SOEs.

Helmich and Gilroy (2012) shed light on how succession happens in SOEs in China, in a context of gradual economic transition, where CEO succession is influenced by the availability of outsider candidates.

Silveira and Dias (2010) analyzed the impact of bad governance practices in 24 cases of conflicts between shareholder groups reported in the specialized media in a concentrated ownership environment, as is typical in Brazil, finding strong evidence of the presence of agency costs reflected in higher risk and lower share value. Although only two of the 24 cases investigated are related to SOEs, where the government is the controlling shareholder, the conflicts reported highlight how interests diverge between controlling and minority shareholders either for economic or political reasons both in SOEs and in privately controlled companies.

Black, Carvalho, and Gorga (2012) compare governance practices in Brazil and other emerging markets, such as Russia, India, and Korea. They point out that SOEs may need 
different governance requirements to achieve optimal governance.

Black, Carvalho, and Gorga (2010) conclude that board independence and financial disclosure are topics where Brazilian companies lag behind their international peers in 2005, noting recent improvements, especially in new listings with higher standards of governance.

Leal, Carvalhal, and Iervolino (2015) research the evolution of corporate governance practices in Brazil in the last decade, and find overall positive signs. Nonetheless, shareholders agreements are still quite common, leveraging the controlling groups and lessening the effective power of outside directors and minority shareholders.

Fernandes and Novaes (2016) analyze the impacts of the government being a major shareholder by measuring the voting premia of dual-class shares trading on the B3 between 2008 and 2012, a period where government interventionism in the economy was high. They conclude that this activism lowers the value of minority votes for business decisions.

Based on this review, we introduce two hypotheses to investigate the relationship between CEO succession in SOEs and political events, considering qualitative and quantitative aspects:

1) H1: CEO turnover in SOEs is greater than in their private peers and is influenced by political processes.

2) H2: CEO turnover in SOEs can generate abnormal returns.

\section{Data \& Methodology}

After the wave of privatization in Brazil that ended in 2002, three SOEs became listed with relevant liquidity on the B3. Banco do Brasil (BB), Eletrobras, and Petrobras are the only SOE stocks in the IBOVESPA index, representing three different and very important sectors of the Brazilian economy: oil and gas, electric energy, and financial services. Eletrobras and Petrobras are companies with dual-class shares, and we analyzed both classes, reporting on only the most liquid stocks.
Although the number of SOEs studied is a limitation, those cases can provide good proxies for succession processes in other SOEs. To try to overcome this limitation, we investigate how succession processes affect SOEs differently, by comparing them with companies that are in the same sectors when possible. Although there are no twin companies, they compete in the same markets and have similar characteristics overall. We also compare if elections affect those proxies in the same way as SOEs.

Analyzing changes in management after elections and comparing with private companies also helps us to understand the uniqueness of the situations SOEs face. To assess the changes in each SOE during every government transition, members of the board of directors or the executive board in the last year of a term are compared with those in the first year of the next term, using official information filed at the CVM, the Brazilian equivalent of the Securities and Exchange Commission in the US.

Since the stabilization of the Brazilian economy in 1994, there have been six presidential elections. First-term incumbents can run for re-election and every elected president has been able to secure re-election for another term, from Fernando Henrique Cardoso (FHC) up to Dilma Rousseff. Rousseff was impeached in 2016 and succeed by her vice-president Michel Temer, thus meaning a total of 7 political processes of interest.

As per Table 1, the tenure of CEOs of SOEs in Brazil is dependent on the political process and affected by general elections. For some of the SOEs studied, CEOs' tenures can be compared to their direct private competitors:

- BB's main competitors addressed CEO successions according to succession planning. Itaú changed CEO only once and Bradesco changed CEOs twice in the period analyzed, while BB had 10 CEOs in the same period.

- Eletrobras has good proxies in Engie Brasil and in CPFL Energia. During the period analyzed, Engie and CPFL Energia 
had 2 CEOs each, while Eletrobras had 10 CEOs. In fact, Engie was a successful spun-off of Eletrobras that was privatized in 1997 and the current CEO of Eletrobras spent 18 years as CEO of CPFL Energia.

- For Petrobras, the closest proxy is Ultrapar, which is also involved in petrochemicals and fuel distribution. Ultrapar had 3
CEOs after 1981, while Petrobras had 10 CEOs after 1994, a much shorter period.

From these examples, we can infer that the tenure of the CEOs of Brazilian SOEs is shorter than that of their national competitors and the international and industry averages consulted. Table 1 summarizes information about the many CEOs each president has appointed to SOEs.

Table 1

Presidents in Brazil and number of CEOs of SOEs

\begin{tabular}{lcccccc}
\hline Date & Election Round & President & Term & Banco Brasil & Eletrobras & Petrobras \\
\hline Oct $3^{\text {rd }}, 1994$ & 1 & FHC & $1995-1998$ & 1 & 3 & 1 \\
Oct $4^{\text {th }}, 1998$ & 1 & FHC & $1998-2002$ & 3 & $3^{\text {a }}$ & 3 \\
Oct $27^{\text {th }}, 2002$ & 2 & Lula & $2002-2006$ & $3^{\text {a }}$ & 3 & $2^{\text {a }}$ \\
Oct $29^{\text {th }}, 2006$ & 2 & Lula & $2006-2010$ & $2^{\text {a }}$ & $3^{\text {a }}$ & 1 \\
Oct $31^{\text {st }}, 2010$ & 2 & Rousseff & $2010-2014$ & 1 & $2^{\text {a }}$ & 1 \\
Oct $26^{\text {th }}, 2014$ & 2 & Rousseff & $2014-2016 *$ & 2 & $1^{\text {a }}$ & 1 \\
May $12^{\text {th }}, 2016$ & Impeachment & Temer & $2016-$ & 1 & 1 & 2 \\
& & & Total CEOs & 11 & 12 & 10 \\
\hline
\end{tabular}

${ }^{a}$ CEOs kept from one term to the next. Total CEOs eliminates duplicates.

On average, the CEOs of SOEs were changed every 2 years, their tenures being about $20 \%$ of the SP\&500 average in 2014 (9.9 years), according to the 2015 edition of CEO Succession Practices.

The managerial discretion of CEOs in SOEs is lower than in private companies. There is limited power for CEOs to hire or dismiss their teams, as the executive board is also appointed by the president of Brazil. The board fulfills the role of naming and dismissing executives, but it is mostly appointed by the federal government and has little independence.

In every government election and in government transitions there were important impacts on SOEs, involving several changes in top management and in strategic orientation.

We mapped all CEO succession processes in the SOEs studied since the presidential election of 1994 . We collected and analyzed all changes in top management using documents filed at the CVM, paying special attention to changes after elections.

Official information such as board composition, including short biographies of the main executives, was retrieved from the CVM's and from each company's website. The executive biographies were used to classify them as insiders (with industry knowledge) or outsiders (with no industry knowledge).

Table 2 lists the CEOs of BB, Petrobras, and Eletrobras appointed by each government, classifying them as insiders or outsiders according to the public archival data available at the CVM containing short CEO biographies. 16 out of 32 changes of CEOs in the SOEs listed happened between election/impeachment dates and the initial 3 months of the new government taking office.

This high level of turnover makes it interesting to investigate market reactions 
to elections and CEO successions in SOEs. By analyzing the impacts of successions in federal government and in the management of SOEs since 1994, we can provide insights into governance that have not been systematically analyzed before.

The quotations of the stocks listed in the $\mathrm{B} 3$ and the IBOVEPA benchmark index from
1994 until June $30^{\text {th }}$ of 2018 were obtained from the Economática database.

The next three subsections will provide descriptive information about the SOEs studied and the last subsection will detail the methodology used in this study.

Table 2

\section{CEOs of SOEs}

\begin{tabular}{|c|c|c|c|c|}
\hline CEO & Insider & Initial Date & End Date & Government \\
\hline \multicolumn{5}{|l|}{ Panel A: Banco do Brasil } \\
\hline Paulo Cesar Ximenes & Yes & Feb, $16-1995$ & Jan, 06 - 1999 & $\underline{\mathrm{FHC}}$ \\
\hline Andrea Calabi & No & Jan, 06 - 1999 & Jul, 29 - 1999 & $\underline{\mathrm{FHC}}$ \\
\hline Paolo Zaghen & No & Jul, 29 - 1999 & Mar, $28-2001$ & FHC \\
\hline Eduardo Guimarães & No & Mar, $28-2001$ & Jan, 29 - 2003 & FHC \\
\hline Cassio Casseb & No & Jan, $29-2003$ & Nov, $17-2004$ & $\underline{\text { Lula }}$ \\
\hline Rossano Pinto & Yes & Nov, $17-2004$ & Dec, $11-2006$ & Lula \\
\hline Antonio Lima Neto & Yes & Dec, $11-2006$ & Apr, 08 - 2009 & $\underline{\text { Lula }}$ \\
\hline Aldemir Bendine & Yes & Apr, 08 - 2009 & Feb, $06-2015$ & Lula \\
\hline Alexandre Abreu & Yes & Feb, $06-2015$ & May, 31 - 2016 & $\underline{\text { Rousseff }}$ \\
\hline$\underline{\text { Paulo Caffarelli }}$ & $\underline{\text { Yes }}$ & May, $31-2016$ & - & $\underline{\text { Temer }}$ \\
\hline \multicolumn{5}{|l|}{ Panel B: Eletrobras } \\
\hline Mario Fernando Melo Santos & Yes & Jan, $02-1995$ & May, 04 - 1995 & $\underline{\mathrm{FHC}}$ \\
\hline Antônio Imbassahy & No & May, $04-1995$ & May, 29 - 1996 & $\mathrm{FHC}$ \\
\hline Firmino Ferreira Sampaio b & No & May, 29 - 1996 & Apr, $09-2001$ & FHC \\
\hline Cláudio Ávila da Silva & No & Apr, $09-2001$ & Apr, $01-2002$ & FHC \\
\hline Altino Ventura Filho & Yes & Apr, $01-2002$ & Jan, $14-2003$ & FHC \\
\hline Luiz Pinguelli Rosa & No & Jan, $14-2003$ & May, $12-2004$ & $\underline{\text { Lula }}$ \\
\hline Silas Rondeau & No & May, $12-2004$ & Jul,11 - 2005 & Lula \\
\hline Aloísio Vasconcelos Novais & No & Jul, $11-2005$ & Jan, $02-2007$ & Lula \\
\hline Valter Luiz Cardeal & Yes & 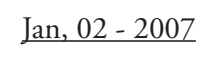 & Mar, $10-2008$ & Lula \\
\hline José Antonio Muniz Lopes ${ }^{\text {b }}$ & Yes & Mar, $10-2008$ & Feb, $28-2011$ & Lula \\
\hline José da Costa Carvalho b & Yes & Feb, $28-2011$ & Jun, $01-2016$ & $\underline{\text { Rousseff }}$ \\
\hline Wilson Ferreira Júnior & $\underline{\text { No }}$ & Jun, $01-2016$ & - & $\underline{\text { Temer }}$ \\
\hline \multicolumn{5}{|l|}{ Panel C: Petrobras } \\
\hline Joel Mendes Rennó ${ }^{b}$ & Yes & Jan, $01-1995$ & Mar, 08 - 1999 & $\underline{\mathrm{FHC}}$ \\
\hline José Coutinho Barbosa & Yes & Mar, 08 - 1999 & Mar, 24 -1999 & $\underline{\mathrm{FHC}}$ \\
\hline Henri Philippe Reichstul & No & Mar, 24 - 1999 & Jan, 02 - 2002 & FHC \\
\hline Francisco Gros & No & Jan, 02 - 2002 & Jan, 02 - 2003 & FHC \\
\hline José Eduardo Dutra & Yes & Jan, 02 - 2003 & Jul, 22 - 2005 & $\underline{\text { Lula }}$ \\
\hline
\end{tabular}




\begin{tabular}{lcccc}
\hline CEO & Insider & Initial Date & End Date & Government \\
\hline Sergio Gabrielli ${ }^{b}$ & Yes & Jul, 22 - 2005 & Feb, 13-2012 & Lula \\
Maria das Graças Foster & Yes & Feb, 13-2012 & Feb, 06-2015 & Rousseff \\
Aldemir Bendine & No & Feb, 06-2015 & May, 30-2016 & $\underline{\text { Rousseff }}$ \\
Pedro Parente & No & May, 30 - 2016 & Jun, 01-2018 & $\underline{\text { Temer }}$ \\
Ivan Monteiro & No & Jun, 01-2018 & & Temer \\
\hline
\end{tabular}

${ }^{\mathrm{b}} \mathrm{CEO}$ s with mandates renewed from one government to the next.

Changes of CEO following elections in italics/underlined.

\section{I Banco do Brasil}

BB has been the leading state-owned bank in Brazil for over 200 years. BB is a commercial bank with over 5000 retail branches in Brazil and international operations in more than 40 countries.

The bank is controlled by the National Treasury, which holds $54 \%$ of the voting shares. Its market value was close to US\$ 20 billion in June 2018. In 1996, BB received a capital injection of close to US\$ 6 billion from the National Treasury to strengthen its balance sheet and deal with huge losses from bad loans to the agribusiness sector, a key sector for Brazil. The bank fulfills the role of implementing public policies on behalf of the government in the sector and provides access to cheaper ear-marked funding in order to do so.

$\mathrm{BB}$ had 4 different CEOs under FHC ( 1 insider), 4 under Lula ( 1 outsider), and 2 insiders under Rousseff, roughly one CEO every 18 months since 1994, as shown in Table 2 - Panel A. All the CEOs were either career employees (insiders) or economists with a financial background (outsiders).

In 2006, BB joined the B3's "Novo Mercado" listing segment of best governance practices, after unifying its share classes; it is the only SOE listed on it.

\subsection{Eletrobras}

Eletrobras is a holding company in the electricity sector responsible for $37 \%$ of energy generation and $57 \%$ of energy transmission in
Brazil. Eletrobras had a market value close to US\$ 5 billion in June 2018, and is controlled by the National Treasury, which holds $54 \%$ of the voting shares (the most liquid ones).

Eletrobras controls large generation and transmission subsidiaries and some small utilities in poorer states in Brazil that are being prepared for privatization. The company also has many minority or co-controlled investments, in partnerships with private companies.

The energy sector is regulated and most of its companies are or have been SOEs. Most CEOs have an engineering background and have forged a career in the sector, and many have political connections.

In Table 2 - Panel B, we only classify as insiders those CEOs with previous experience in the Eletrobras conglomerate, while the outsiders generally had experience at the state rather than federal level in the sector. Several of the CEOs had previous experiences either at subsidiaries of Eletrobras or state-level SOEs.

Eletrobras had 5 different CEOs under President FHC, 5 under Lula, and 1 under Rousseff, who had years of previous experience in the sector as energy secretary of Rio Grande do Sul state and Energy Minister and Chairwoman of Eletrobras under Lula's presidency. Eletrobras had roughly one CEO every 18 months since 1994.

Due to governance problems, Eletrobras settled a class action lawsuit in the US as some of its investments were investigated in "Operation Car Wash.” Investors questioned accounting standards for several investments from 2009 to 
2014. External auditors have also been reluctant to approve its financial statements.

\section{$3 \cdot 3$ Petrobras}

Petrobras is the giant national oil company, with a market value of over US\$ 65 billion in June 2018. It is the $5^{\text {th }}$ largest listed oil company in the world, and historically the most important company in Brazil. Petrobras was able to raise US\$ 70 billion in 2010, the largest public offering in history so far, in a context of high oil prices and a bullish outlook for the company and for Brazil. The National Treasury of Brazil controls Petrobras, holding $50.26 \%$ of the voting capital. Petrobras is a company of dual-class shares and the preferred shares are the most liquid.

A market leader with huge technical expertise in identifying and extracting oil in ultra-deep fields, Petrobras was hurt by its huge indebtedness following a heavy investment program, now known to be linked to the corruption scandal investigated in the "Car Wash" investigation.

External auditors have been reluctant to approve its financial statements since the scandal emerged, in the third quarter of 2014. Petrobras' balance sheet has been affected by the corruption scandal, with losses of nearly US\$17 billion in write-downs and impairments being recognized. Petrobras is settling class action lawsuits with international investors, amounting to close to US\$ 3 billion. Several former executives of Petrobras are already in jail.

Petrobras grew a lot, investing in the pre-salt discoveries and in refineries. Huge losses in ill-designed projects with cost overruns, now known to be directly affected by the corruption scandal, and populism in the form of price fixing have increased its indebtedness, which is the highest in the world.

With the company being at the center of the corruption scandal and it facing high leverage and uncertainty, Petrobras' stock prices were depressed until the new administration in 2016 started to regain market confidence.
Table 2 - Panel C shows that during President FHC's two terms, Petrobras had 4 different CEOs, while during Lula's two terms it had 2 CEOs. President Rousseff (previously Energy Minister and Chairwoman of Petrobras in Lula's government) appointed 3 different CEOs in five and a half years. President Temer appointed 2 CEOs in 30 months, as Ivan Monteiro, then CFO, took over as successor to Pedro Parente, who resigned over claims of political interference in Petrobras' pricing policy.

Recent evidence shows that the recovery process of Petrobras is still affected by political interference, where independent pricing policies are in conflict with the government's political objectives.

The 2018 succession process at Petrobras was the only one implemented under law $n^{\circ}$ 13,303/2016. From analyzing its outcome and discussions about Petrobras's policies since them, it is clear that this law was not able to shield SOEs completely from political interference and political use by their controllers.

On average, Petrobras changed CEO every two years. The average tenure of CEOs at the company since 1994 has been well below the industry average, which is 4.6 years according to a global survey by the Oil \& Gas Financial Journal.

Petrobras' CEOs come from a mixed background, with some coming from the financial sector (outsiders) and some from within the company (insiders).

\subsection{Event Study Methodology}

Using short-horizon event studies, the impact of elections and CEO succession processes on the selected SOEs since the 1994 election is analyzed longitudinally.

According to Kothari and Warner (2007), event studies are a workhorse of empirical finance due to their simplicity, despite their known limitations. Event studies are implemented here as a one-factor model (using the market model), and we chose to use a simple OLS model, not adjusted for heteroscedasticity, as there is naturally more 
volatility in markets prior to election periods, hence more variance. Succession processes are also prone to more volatility, but those characteristics do not contaminate short-horizon event studies, especially on the day of the event and in short windows around it.

Several succession studies have used event studies to identify abnormal returns (ARs) and changes in market perception. A standard framework for event studies is used, measuring ARs on the day of the event and CARs over different windows around the day of the event. The IBOVESPA index is considered as the market return and parameters specific to each stock were obtained through regressions of standard previous periods. AR is calculated as the difference between real stock returns and expected stock returns according to the market model over the windows of interest.

In all the event studies, carried out using the Event Study Metrics Software, an estimation window of 120 trading days finishing 15 days before the event (election date or succession date) was used. To estimate returns and calculate abnormal returns, we used the market model with parameters calculated through regressions using the IBOVESPA index as the market return, according to the equation:

$$
\text { ExpRet }_{\mathrm{t}}=\text { Alpha } \text { Beta }^{*} \text { IBOVESPA }_{t}+\text { Error }_{\mathrm{t}}[1]
$$

The parameters of the market model are estimated using an ordinary least squares (OLS) regression. Using equation (1), we estimate the difference between realized and expected returns and the generation of abnormal returns, on the day of the event and in short windows around the day of the event.

Cross-sectional event studies were also performed comparing how the events affected several companies on a given date or affected a set of companies over time. Kolari/ Pynnonen cross-correlational adjustments were used to avoid concerns of cross-sectional dependence through over rejection of the null hypotheses of no mean effect.

This framework was used for studying two types of events and their impacts on the SOEs: presidential election dates and CEO succession dates.

Event studies related to each election were performed for each SOE for major political events.

After analyzing the impact of the political processes, we examined individual CEO succession processes in SOEs, covering 32 successions in SOEs using the same event study methodology. CEOs are classified as insiders or outsiders according to their biographies, following the literature.

\section{Results}

The number of succession processes in SOEs in Table 1 is much higher than average, making it worthwhile to investigate which specific characteristics differentiate them. Table 2 illustrates how political events are often related to CEO successions in SOEs. In Table 3, which presents a summary of the changes in the top management teams (TMTs) of the SOEs after election years, it is clear that power shifts cause greater turnover in management than reelections or continuity governments. 
Table 3

Changes in Top Management Teams filed at CVM after election years

\begin{tabular}{lccc}
\hline Election - Election + 1 year & $\begin{array}{c}\text { \% change of TMT in Banco } \\
\text { do Brasil }\end{array}$ & $\begin{array}{c}\text { \% change of TMT in } \\
\text { Eletrobras }\end{array}$ & $\begin{array}{c}\text { \% change of TMT in } \\
\text { Petrobras }\end{array}$ \\
\hline 1998-1999 (FHC1- FHC2) & $57,14 \%$ & $22,22 \%$ & $7,14 \%$ \\
$\mathbf{2 0 0 2}$-2003 (FHC-Lula)* & $\mathbf{8 6 , 6 7 \%}$ & $\mathbf{7 1 , 4 3 \%}$ & $\mathbf{8 0 , 0 0 \%}$ \\
$2006-2007$ (Lula1-Lula2) & $37,50 \%$ & $38,46 \%$ & $11,76 \%$ \\
$2010-2011$ (Lula-Dilma) & $18,75 \%$ & $50,00 \%$ & $47,05 \%$ \\
$2014-2015$ (Dilma1-Dilma2) & $29,41 \%$ & $42,86 \%$ & $88,23 \%$ \\
$\mathbf{2 0 1 5 - 2 0 1 6}$ (Dilma-Temer)* & $\mathbf{8 8 , 2 3 \%}$ & $\mathbf{8 1 , 2 5 \%}$ & $\mathbf{3 1 , 2 5 \%}$ \\
\hline
\end{tabular}

* power shifts between political parties, highlighted in bold, showing greater turnover in the TMTs than reelections or elections that represent continuity. In these cases, the cascading effects and changes in strategy tend to be much higher than in a continuity scenario.

Tables 2 and 3 provide evidence of the influence of political processes on CEO turnover and top management team changes in the SOEs, as postulated in our first hypothesis.

Every power transition has multiple and multilevel effects on companies, with changes in priorities and in top management cascading into middle management. The organizational structure is often impacted and symbolic aspects of the marketing and public image of the companies can change.

By affecting management, elections and CEO successions for political reasons may influence performance differently from in the case of competitors in the sectors SOEs operate. Although succession planning is important, in
Brazilian SOEs succession planning is unviable at the top level, because of the impacts of political processes on top management. Clear evidence of this is that CEO turnover in SOEs occurs much more often than in their privately owned peers.

To investigate our second hypothesis, regarding the generation of abnormal returns indirectly with political events and directly with CEO successions, we used two sets of event studies, as shown in Tables 4 and 5 .

Following the literature, we investigated if political events could generate abnormal returns and if they affect SOEs more often than their proxies. For each event, the CAR was calculated in windows of 1,5 , and 10 days before and after the event. 
Table 4

Impacts on SOEs of political events

\begin{tabular}{|c|c|c|c|c|c|c|c|c|c|}
\hline & \multirow[b]{2}{*}{$\begin{array}{c}\text { window } \\
\text { size }\end{array}$} & \multicolumn{2}{|c|}{$\begin{array}{c}\text { Banco do } \\
\text { Brasil }\end{array}$} & \multicolumn{2}{|c|}{ Eletrobras } & \multicolumn{2}{|c|}{ Petrobras } & \multicolumn{2}{|c|}{ Cross-Section SOEs } \\
\hline & & RAC & $\mathbf{t}$ & CAR & $\mathbf{t}$ & CAR & $\mathbf{t}$ & CAR & t-cross \\
\hline \multirow{4}{*}{1994 election } & 0 & $2,16 \%$ & 0,46 & $-3,81 \%$ & $-0,83$ & $-5,97 \%$ & $-1,22$ & $-2,50 \%$ & $-1,05$ \\
\hline & 1 & $0,84 \%$ & 0,1 & $-6,93 \%$ & $-0,87$ & $-9,88 \%$ & $-1,16$ & $-5,30 \%$ & $-1,66$ \\
\hline & 5 & $-17,28 \%$ & $-1,11$ & $-17,80 \%$ & $-1,16$ & $-18,30 \%$ & $-1,12$ & $-17,79 \%$ & $-59,86^{* *}$ \\
\hline & 10 & $-32,05 \%$ & $-1,48$ & $-25,52 \%$ & $-1,21$ & $-33,46 \%$ & $-1,49$ & $-30,35 \%$ & $-12,41^{* *}$ \\
\hline \multirow{4}{*}{1998 election } & 0 & $-0,45 \%$ & $-0,12$ & $-0,81 \%$ & $-0,26$ & $-0,17 \%$ & $-0,09$ & $-0,48 \%$ & $-2,58^{* *}$ \\
\hline & 1 & $0,18 \%$ & 0,03 & $-4,42 \%$ & $-0,83$ & $-0,33 \%$ & $-0,1$ & $-1,52 \%$ & $-1,05$ \\
\hline & 5 & $1,53 \%$ & 0,13 & $-0,37 \%$ & $-0,04$ & $9,58 \%$ & 1,46 & $3,58 \%$ & 1,17 \\
\hline & 10 & $-16,23 \%$ & $-0,97$ & $8,02 \%$ & 0,57 & $23,83 \%$ & $2,62^{* *}$ & $5,21 \%$ & 0,45 \\
\hline \multirow{4}{*}{2002 election } & 0 & $-1,10 \%$ & $-0,39$ & $3,77 \%$ & 1,69 & $0,70 \%$ & 0,35 & $1,12 \%$ & 0,79 \\
\hline & 1 & $1,80 \%$ & 0,36 & $11,22 \%$ & $2,90^{* *}$ & $-2,13 \%$ & $-0,61$ & $3,63 \%$ & 0,92 \\
\hline & 5 & $-0,51 \%$ & $-0,05$ & $17,24 \%$ & $2,32 *$ & $1,24 \%$ & 0,19 & $5,99 \%$ & 1,06 \\
\hline & 10 & $-0,81 \%$ & $-0,06$ & $2,29 \%$ & 0,22 & $7,76 \%$ & 0,85 & $3,08 \%$ & 1,22 \\
\hline \multirow{4}{*}{2006 election } & 0 & $0,61 \%$ & 0,26 & $-2,42 \%$ & $-1,2$ & $-0,24 \%$ & $-0,19$ & $-0,68 \%$ & $-0,75$ \\
\hline & 1 & $1,47 \%$ & 0,36 & $-1,90 \%$ & $-0,55$ & $0,44 \%$ & 0,2 & $0,00 \%$ & 0 \\
\hline & 5 & $2,97 \%$ & 0,38 & $-6,30 \%$ & $-0,94$ & $4,22 \%$ & 1,02 & $0,30 \%$ & 0,09 \\
\hline & 10 & $1,94 \%$ & 0,18 & $-13,91 \%$ & $-1,51$ & $5,48 \%$ & 0,95 & $-2,16 \%$ & $-0,36$ \\
\hline \multirow{4}{*}{2010 election } & 0 & $0,47 \%$ & 0,32 & $2,17 \%$ & 1,91 & $1,49 \%$ & 0,97 & $1,37 \%$ & $2,78^{* *}$ \\
\hline & 1 & $-0,13 \%$ & $-0,05$ & $1,24 \%$ & 0,63 & $1,85 \%$ & 0,7 & $0,99 \%$ & 1,68 \\
\hline & 5 & $-3,13 \%$ & $-0,65$ & $-1,70 \%$ & $-0,45$ & $11,35 \%$ & $2,23^{*}$ & $2,17 \%$ & 0,47 \\
\hline & 10 & $-2,13 \%$ & $-0,32$ & $-12,66 \%$ & $-2,43^{*}$ & $4,56 \%$ & 0,65 & $-3,41 \%$ & $-0,68$ \\
\hline \multirow{4}{*}{2014 election } & 0 & $-1,45 \%$ & $-0,78$ & $-8,12 \%$ & $-3,69^{* *}$ & $-7,17 \%$ & $-5,27^{* *}$ & $-5,58 \%$ & $-2,68^{* *}$ \\
\hline & 1 & $0,05 \%$ & 0,02 & $-4,46 \%$ & $-1,17$ & $-9,10 \%$ & $-3,85^{* *}$ & $-4,50 \%$ & $-1,70$ \\
\hline & 5 & $-11,62 \%$ & $-1,88$ & $-7,55 \%$ & $-1,04$ & $-17,98 \%$ & $-3,98^{* *}$ & $-12,38 \%$ & $-4,08^{* *}$ \\
\hline & 10 & $-13,29 \%$ & $-1,55$ & $0,15 \%$ & 0,01 & $-25,26 \%$ & $-4,05^{* *}$ & $-12,80 \%$ & $-1,74$ \\
\hline \multirow{4}{*}{$\begin{array}{l}2016 \\
\text { Impeach- } \\
\text { ment }\end{array}$} & 0 & $-4,54 \%$ & $-1,57$ & $0,81 \%$ & 0,32 & $-6,41 \%$ & $-2,27^{*}$ & $-3,92 \%$ & $-2,38^{*}$ \\
\hline & 1 & $-5,98 \%$ & $-1,19$ & $3,97 \%$ & 0,92 & $-2,46 \%$ & $-0,5$ & $-1,49 \%$ & $-0,51$ \\
\hline & 5 & $-8,20 \%$ & $-0,85$ & $-9,56 \%$ & $-1,16$ & $0,17 \%$ & 0,02 & $-5,86 \%$ & $-1,92$ \\
\hline & 10 & $-13,32 \%$ & -1 & $15,18 \%$ & 1,33 & $0,91 \%$ & 0,07 & $0,92 \%$ & 0,11 \\
\hline \multirow{3}{*}{ Cross section } & 0 & $-0,61 \%$ & $-0,54$ & $-1,43 \%$ & $-0,97$ & $-2,54 \%$ & $-1,78$ & $-1,53 \%$ & $-2,12^{*}$ \\
\hline & 1 & $-0,25 \%$ & $-0,12$ & $-0,18 \%$ & $-0,08$ & $-3,09 \%$ & $-1,77$ & $-1,17 \%$ & $-1,14$ \\
\hline & 5 & $-5,17 \%$ & 1,83 & $-3,72 \%$ & $-0,91$ & $-1,39 \%$ & $-0,3$ & $-3,43 \%$ & $-1,58$ \\
\hline $\begin{array}{l}\text { Political } \\
\text { event }\end{array}$ & 10 & $-10,84 \%$ & $-2,44^{*}$ & $-3,78 \%$ & 0,71 & $-2,31 \%$ & $-0,31$ & $-5,64 \%$ & $-1,68$ \\
\hline
\end{tabular}

${ }^{*}$ p-value $<0.05 ;{ }^{* *}$ p-value $<0.01$ 
Table 4 summarizes the impacts of relevant political events on the SOEs (elections and Dilma Rousseff's impeachment through a voting process in Congress).

For all major political events, apart from the 2002 and 2006 elections, there are statistically significant ARs/CARs for the set of SOEs investigated, showing that elections can affect SOEs around the day of the event.

Considering each political event's impact on the SOEs:

- FHC's reelection in 1998 yielded a positive CAR for Petrobras over a 10-day window (p-value $<0.01$ ).

- Lula's election in 2002 yielded a positive CAR for Eletrobras over 1-day and 5-day windows ( $\mathrm{p}$-value $<0.01$ and $\mathrm{p}$-value $<$ 0.05 , respectively).

- Rousseff's election in 2010 yielded a negative CAR for Eletrobras over a 5-day window and a positive CAR for Petrobras over a 10-day window ( $\mathrm{p}$-value $<0.01$ ).

- Rousseff's reelection in 2014 affected the SOEs a lot. Petrobras presented negative CARs over all windows tested ( $\mathrm{p}$-value < 0.01). Eletrobras had a negative AR on the election date $(\mathrm{p}$-value $<0.01)$

- Petrobras had a negative AR on the impeachment date ( $\mathrm{p}$-value $<0.05$ ).

The individual event studies on political events for BB showed no significance. Nonetheless, the cross-sectional study of all political events for $\mathrm{BB}$ showed a negative CAR in a 10-day window (p-value $<0.05$ ).

The cross-sectional studies for all political events investigated for the set of SOEs examined revealed a negative AR of $-1.53 \%$ on election dates (p-value $<0.05$ ).

We also carried out some robustness tests to enhance our knowledge regarding the impact of elections on SOEs, testing the same events with private proxies/matching firms when available, as elections can affect private companies as well, but not at the same level.

For instance, CPFL and Engie have the same fundamental economic characteristics but were not affected by the 2010 and 2014 elections, unlike Eletrobras. In 2014, Ultrapar presented a small positive CAR in a 1-day window but was not affected like Petrobras by the election outcome.

Succession processes in SOEs are often motivated by political processes. $50 \%$ of the CEO successions analyzed can be traced back to the previous political process, as highlighted in Table 2. As successions are usually expected after each election, the markets may anticipate top management turnover on election dates, usually a few months before a new government takes office. Moreover, as governments cannot only appoint new management, but also change boards and strategies, elections may be more relevant than successions themselves.

There were more significant results after 2010, providing evidence of the importance of political processes to the market prices of SOEs. Hence, investors should be aware of them.

As Eletrobras and Petrobras have dualclass shares, we repeated the tests using the least liquid stocks of those companies (ELET6 and PETR3) as robustness tests, yielding the same general results.

After looking at elections, we turned our interest to each CEO succession in Table 5, organized in panels for each SOE, and calculated ARs and CARs for windows of 1, 5, and 10 days around the succession dates.

Most of the significant results are from the past few years, signaling that investors should pay more attention to these processes from now on. Investors react accordingly with their convictions on the prospects for a company under new leadership and this should also be considered by governments appointing new CEOs to SOEs. 
Table 5

\section{CEO Successions at SOEs}

\begin{tabular}{|c|c|c|c|c|c|c|c|c|}
\hline $\begin{array}{l}\text { CEO Successions at } \\
\text { SOEs }\end{array}$ & AR & $\mathbf{t}$ & $\begin{array}{c}\text { CAR in } \\
\text { window } \\
(-1,1)\end{array}$ & $\mathbf{t}$ & $\begin{array}{c}\text { CAR in } \\
\text { window } \\
(-5,5)\end{array}$ & $\mathbf{t}$ & $\begin{array}{l}\text { CAR in } \\
\text { window } \\
(-10,10)\end{array}$ & $\mathbf{t}$ \\
\hline \multicolumn{9}{|l|}{ Panel A: BB } \\
\hline Ximenes & $4.79 \%$ & 1.57 & $-1.86 \%$ & -0.35 & $0.37 \%$ & -0.03 & $10.33 \%$ & 0.74 \\
\hline Calabi & $0 \%$ & 0 & $-0.42 \%$ & -0.07 & $0.46 \%$ & 0.43 & $-0.62 \%$ & -0.04 \\
\hline Zaghen & $1.54 \%$ & 0.61 & $2.51 \%$ & 0.58 & $-2.99 \%$ & -0.36 & $-0.40 \%$ & -0.03 \\
\hline Eduardo Guimarães & $2.22 \%$ & 0.89 & $0.37 \%$ & 0.93 & $4.44 \%$ & 0.59 & $15.26 \%$ & 1.33 \\
\hline Casseb & $2.61 \%$ & 1.07 & $-0.07 \%$ & -0.17 & $-1.49 \%$ & -0.17 & $13.47 \%$ & 1.13 \\
\hline Rossano & $-2.72 \%$ & $-2.15^{*}$ & $0.25 \%$ & 0.11 & $-1.25 \%$ & 0.30 & $-2.00 \%$ & -0.34 \\
\hline Lima Neto & $2.40 \%$ & 1.41 & $1.68 \%$ & 0.57 & $-2.39 \%$ & -0.42 & $8.36 \%$ & 1.08 \\
\hline Bendine & $-9.36 \%$ & $-3.14^{* *}$ & -15.18 & $-2.94^{* *}$ & $-4.01 \%$ & -0.4 & $2.47 \%$ & 0.18 \\
\hline Alexandre Abreu & $-2.48 \%$ & -1.19 & $0.38 \%$ & 0.11 & $3.16 \%$ & 0.46 & $-4.69 \%$ & -0.49 \\
\hline Caffarelli & $2.14 \%$ & 0.74 & $2.77 \%$ & 0.55 & $-4.44 \%$ & 0.65 & $-6.06 \%$ & -0.46 \\
\hline Cross BB & $-0.94 \%$ & -0.67 & $-0.96 \%$ & -0.63 & $-0.39 \%$ & -0.43 & $4.21 \%$ & 1.14 \\
\hline \multicolumn{9}{|l|}{ Panel B: Eletrobras } \\
\hline Mario Fernando & $1.65 \%$ & 1.05 & $0.05 \%$ & 0.01 & $4.29 \%$ & 0.82 & $6.37 \%$ & 0.89 \\
\hline Imbassahy & $0.31 \%$ & 0.13 & $0.63 \%$ & 0.16 & $-0.27 \%$ & -0.03 & $0.84 \%$ & 0.08 \\
\hline Firmino & $-0.60 \%$ & -0.54 & $-3.88 \%$ & $-2.03^{*}$ & $-6.64 \%$ & -1.82 & $-4.36 \%$ & -0.86 \\
\hline Claudio Avila & $2.02 \%$ & 0.94 & $-5.63 \%$ & -1.52 & $-14.36 \%$ & $-2.03^{*}$ & $-14.28 \%$ & -1.46 \\
\hline Altino & $0.05 \%$ & 0.02 & $3.32 \%$ & 0.72 & $4.98 \%$ & 0.57 & $1.97 \%$ & 0.16 \\
\hline Pinguelli & $2.70 \%$ & 1.06 & $-1.85 \%$ & -0.42 & $-5.92 \%$ & -0.7 & $-13.08 \%$ & -1.12 \\
\hline Silas Rondeau & $0.39 \%$ & 0.13 & $-2.46 \%$ & -0.47 & $-1.95 \%$ & -0.19 & -3.63 & -0.26 \\
\hline Aluisio Novais & $0.39 \%$ & 0.13 & $-2.46 \%$ & -0.47 & $-1.95 \%$ & -0.19 & -3.63 & -0.26 \\
\hline Valter Cardeal & $-1.03 \%$ & -0.53 & $0.63 \%$ & 0.85 & $-2.23 \%$ & -0.34 & $-3.68 \%$ & -0.41 \\
\hline Muniz Lopes & $0.10 \%$ & 0.04 & $5.04 \%$ & 1.25 & $14.48 \%$ & 1.87 & $8.79 \%$ & 0.82 \\
\hline Costa Carvalho & $1.59 \%$ & 1.00 & $0.53 \%$ & 0.19 & $4.81 \%$ & 0.91 & $2.91 \%$ & 0.4 \\
\hline Wilson Ferreira & $5.43 \%$ & $2.00^{*}$ & $5.33 \%$ & 1.13 & $9.96 \%$ & 1.11 & $11.93 \%$ & 0.96 \\
\hline Cross Petrobras & $1.33 \%$ & $2.49^{*}$ & $0.62 \%$ & 0.58 & $0.60 \%$ & 0.28 & $-1.82 \%$ & -0.62 \\
\hline \multicolumn{9}{|l|}{ Panel C: Petrobras } \\
\hline Joel Renno & $-0.72 \%$ & -0.42 & $-0.09 \%$ & -0.03 & $-0.51 \%$ & -0.09 & $-1.04 \%$ & -0.13 \\
\hline Jose Barbosa & $0.72 \%$ & 0.56 & $7.21 \%$ & 1.36 & $17.29 \%$ & 1.7 & $17.78 \%$ & 1.26 \\
\hline Reichtul & $-3.22 \%$ & 1.16 & $1.86 \%$ & 0.39 & $11.24 \%$ & 1.22 & $19.33 \%$ & 1.53 \\
\hline Gros & $-0.94 \%$ & -0.44 & $-0.21 \%$ & -0.06 & $1.44 \%$ & 0.2 & $0.62 \%$ & 0.06 \\
\hline Dutra & $-1.34 \%$ & -0.75 & $-2.63 \%$ & -0.85 & $0.00 \%$ & -0.02 & $3.11 \%$ & 0.38 \\
\hline Gabrielli & $2.72 \%$ & $2.22^{*}$ & $3.91 \%$ & 1.85 & $-0.68 \%$ & -0.17 & $-1.81 \%$ & -0.32 \\
\hline Graça Foster & $0.89 \%$ & 0.92 & $-8.75 \%$ & $-5.18^{* *}$ & $-4.73 \%$ & -1.46 & $-6.84 \%$ & -1.53 \\
\hline Bendine & $-5.02 \%$ & $-2.17^{*}$ & $-6.89 \%$ & -1.72 & $5.65 \%$ & 0.74 & $-5.69 \%$ & -0.54 \\
\hline Parente & $2.15 \%$ & 0.78 & $-3.39 \%$ & -0.7 & $-7.09 \%$ & -0.77 & $1.15 \%$ & 0.09 \\
\hline Monteiro & $-17.29 \%$ & $-13.17^{* *}$ & $-15.41 \%$ & $-6.77^{* *}$ & $-28.23 \%$ & $-6.48^{* *}$ & $-32.74 \%$ & $-5.46^{* *}$ \\
\hline Cross Petrobras & $-2.10 \%$ & -1.13 & $-2.44 \%$ & 0.013 & $-0.57 \%$ & -0.15 & $-0.61 \%$ & -0.13 \\
\hline
\end{tabular}

* $\mathrm{p}$-value $<0.05 ;{ }^{* *} \mathrm{p}$-value $<0.01$ 
For BB, two out of ten processes had negative ARs on succession dates (Rossano and Bendine). The last one also had a negative CAR in a 1 -day window ( $\mathrm{p}$-value $<0.01$ ).

Two out of twelve of the succession processes at Eletrobras had negative CARs (Firmino and Claudio Avila), in 1-day and 5-day windows, respectively ( $\mathrm{p}$-value $<0.05$ ).

In the case of Petrobras, succession processes caused more impact, with four succession processes out of ten generating abnormal returns:

- A positive AR on the succession date in 2005, (Gabrielli - p-value < 0.05).

- A negative CAR over a 1-day window in 2012, (Graça Foster - p-value < 0.01).

- A negative AR on the succession date in 2015, (Bendine - p-value < 0.05).

- A negative AR on the succession date and negative CARs in all windows when Parente quit his position as CEO in 2018 and Monteiro was nominated ( $\mathrm{p}$-value $<0.01)$. This happened after a national strike of truck drivers almost halted the Brazilian economy. The strike was attributed to Petrobras' pricing policy and the underperformance was attributed to the strike and to pressures to change the company's pricing policy, which happened. After Monteiro took office returns were positive, although not significant in windows after the succession, with the stock trading broadly in line with the index after Parente's resignation.

Cross-sectional tests involving the 32 successions in the SOEs studied showed that there are no generally significant impacts on the stock prices. Nonetheless, the 12 succession processes at Eletrobras generated a small positive AR ( $\mathrm{p}$-value $<0.05$ )

As Eletrobras and Petrobras have dual-class shares, we repeated the tests using the least liquid stocks of those companies (ELET6 and PETR3), yielding the same general results.

\section{Conclusions}

SOEs are different from private companies in many ways, including their succession processes, as political events can cause changes in management, affecting market perceptions.

Changes in government are usually followed by changes in SOEs. Changes are greater when power shifts happen. Even when the incumbent wins, changes in top management teams take place as a result of political negotiations, making the analysis of those events relevant.

Using a set of event studies we were able to show that there is some but not a general impact of political events on SOEs. Recently, this became more frequent and relevant to investors.

Succession processes in SOEs are more common than in private companies, as they are linked to the political and electoral processes. SOE CEOs have shorter tenures than their privatesector peers and need to be reconfirmed after general elections.

As they have limited room for appointing their teams, limited managerial discretion, and fewer incentives, it is not easy to make direct links between the CEO effect and performance in SOEs. Nonetheless, the impacts of political events and succession processes must be considered by investors.

The performance of SOEs in the B3 over the past two decades has been irregular, linked to the Brazilian economy and to the strategies defined by the government.

Politically motivated decisions and changes in management to accommodate political allies have not helped their performance, which may explain why Congress approved Law $13,303 / 2016$, which tries to improve governance, disclosure, and decision making in SOEs, addressing the political scandals widely discussed in Brazil. Nonetheless, political interference is still possible and can harm the performance of SOEs.

This paper contributes to the literature on $\mathrm{CEO}$ successions by examining the unique role that political events play in CEO successions at SOEs. By analyzing the market impacts of 
elections and CEO successions and documenting the patterns of changes in the top management of SOEs after elections it also contributes to the corporate governance literature on SOEs.

This study has several limitations. Event studies are useful, but their limitations are well known. Often, it is hard to untangle effects when other situations happening simultaneously with the event affect the company or the market.

We analyzed three SOEs individually in seven voting processes, but it is hard to generalize the results. In several cases, when it is clear who the winner will be, election dates may not be the best choices for event studies or information linked to the elections may already be factored into prices on election dates. More fiercely-disputed elections, with winners defined by a narrow margin, such as Rousseff's reelection in 2014, cause more uncertainty and generate abnormal returns more frequently.

When analyzing individual succession processes, there are often differences between when succession rumors start and when succession takes place. Political negotiations to nominate a new CEO may last for a while. We only considered succession dates as it is hard to date rumors. The use of windows of different lengths mitigates this concern, but political decisions can take longer than expected. Other factors may affect stock performance surrounding CEO succession dates and event studies may not capture them. Crises are a common factor for succession, but a CEO may be replaced even when doing a good job if he or she loses political support.

Even with those limitations, this investigation shed light on understudied phenomena that happen frequently in Brazil: CEO successions in SOEs and the impact of elections on SOEs, which can be often related.

Advances in the governance of SOEs have taken place in Brazil after the corruption scandals and these may mitigate relevant issues that historically affected SOEs. Nonetheless, investors should continue to be aware of possible political interference having impacts on SOEs.
Currently in Brazil, there are important discussions about the role of SOEs in the Brazilian economy. This paper may also be relevant to discussions about the privatization of listed SOEs and the role of regulators in avoiding abuses by controlling shareholders.

Suggestions for future research include analyzing the impact of CEO succession on the financial results of SOEs, studying succession at state-level SOEs, and the impacts of Law $13,303 / 2016$ on succession processes in SOEs. Further research could also compare the impacts of elections and succession processes in other countries with important listed SOEs.

\section{References}

Andres, L., Guasch, J. L., \& Azumendi, S. L. (2011). Governance in State-Owned Enterprises Revisited: The cases of water and electricity in Latin America and the Caribbean. World Bank Policy Research Working Paper, 1(1). Retrieved from https://ssrn.com/abstract $=1903506$

Berns, K., \& Klarner, P. (2017). A Review of the CEO succession Literature and a Future Research Program. Academy of Management Perspectives, 31(2), 83-108. doi: https://doi.org/10.5465/ amp.2015.0183.

Białkowski, J., Gottschalk, K., \& Wisniewski, T. P. (2008), Stock market volatility around national elections. Journal of Banking \& Finance, 32(9), 2008, 1941-1953. doi: https://doi.org/10.1016/j. jbankfin.2007.12.021

Black, B. S., Carvalho, A. G. de, \& Gorga, E. (2010). Corporate governance in Brazil. Emerging Markets Review, 11(1), 21-38. doi: https://doi. org/10.1016/j.ememar.2009.09.004

Black, B. S., Carvalho. A., G. de, \& Gorga, E. (2012). What matters and for which firms for corporate governance in emerging markets? Evidence from Brazil (and other BRIC countries). Journal of Corporate Finance, 18(4), 934-952. doi: https://doi.org/10.1016/j.jcorpfin.2011.10.001 
Brogaard, J., \& Detzel, A. (2015). The asset-pricing implications of government economic policy uncertainty. Management Science, 61(1), 3-18. doi: https://dx.doi.org/10.2139/ssrn.2075375

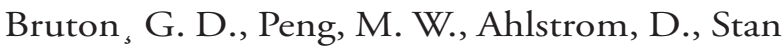
C., \& Xu, K. (2014). State-owned enterprises around the world as hybrid organizations. Academy of Management Perspectives, 29 (1), 92-114. doi: https://doi.org/10.5465/amp.2013.0069

Carvalho, D. (2014). The real effects of government-owned banks: Evidence from an emerging market. Journal of Finance (John Wiley \& Sons, Inc.), 69(2), 577-609. doi: https://doi. org/10.1111/jofi.12130

CEO Succession Practices (2015)- The Conference Board. Retrieved from https://www.conferenceboard.org/publications/publicationdetail. cfm?publicationid $=2935$

Chang, E. C., \& Wong, S. M. L. (2009) Governance with multiple objectives: Evidence top executive turnover in China. Journal of Corporate Finance, 15(2), 2009, 230-244. doi: https://doi.org/10.1016/j.jcorpfin.2008.10.003

Charan, R. (2005). Ending the CEO succession crisis. Harvard Business Review, 83(2), 72-81. doi: https://doi.org/10.2307/1336931

Christiansen, H. (2011). The Size and Composition of the SOE sector in OECD countries. OECD Corporate Governance Working Papers, No. 5, OECD Publishing, Paris, https:// doi.org/10.1787/5kg54cwps0s3-en

Connelly, B. L., Ketchen, D. J., Gangloff, K. A., \& Shook, C. L. (2016). Investor perceptions of $\mathrm{CEO}$ successor selection in the wake of integrity and competence failures: A policy capturing study. Strategic Management Journal (John Wiley \& Sons, Inc.), 37(10), 2135-2151. doi: https:// doi.org/10.1002/smj. 2430

Crossland, C., \& Chen, G. (2013). Executive accountability around the world:
Sources of cross-national variation in firm performance-CEO dismissal sensitivity. Strategic Organization, 11(1), 78-109. doi: https://doi. org/10.1177/1476127012460946

Crossland, C., \& Hambrick, D. C. (2011). Differences in managerial discretion across countries: How nation-level institutions affect the degree to which CEOs matter. Strategic Management Journal (John Wiley \& Sons, Inc.), 32(8), 797-819. doi: https://doi.org/10.1002/smj.913

Datta, D. K., \& Rajagopalan, N. (1998). Industry structure and CEO characteristics: An empirical study of succession events. Strategic Management Journal (John Wiley \& Sons, Inc.), 19(9), 833-852. doi: https://doi.org/10.1002/ (SICI) 1097-0266(199809) 19:9<833::AIDSMJ971>3.0.CO;2-V

Fernandes, M., \& Novaes, W. (2016). The government as a large shareholder: Impact on corporate governance. [Working Paper $\mathrm{n}^{\circ} 40$ ]. Fundação Getúlio Vargas, São Paulo.

Ferris, S. P., Jayaraman, N., \& Jongha, L. (2015). Six decades of CEO successions: The importance of being an insider. Journal of Accounting \& Finance (2158-3625), 15(4), 11-39.

Gangloff, K. A., Connelly, B. L., \& Shook, C. L. (2014). Of scapegoats and signals: Investor reactions to CEO succession in the aftermath of wrongdoing. Journal of Management, 42 (6), 1614-1634. doi: https:// doi.org/10.1177/0149206313515521

Giambatista, R. C., Rowe, W. G., \& Riaz, S. (2005). Nothing succeeds like succession: A critical review of leader succession literature since 1994. The Leadership Quarterly, 16(6), 963-991. doi: https://doi.org/10.1016/j.leaqua.2005.09.005

Guo, L., \& Masulis, R. W. (2015). Board structure and monitoring: New evidence CEO turnovers. Review of Financial Studies, 28(10), 2770-2811. doi: https://doi.org/10.1093/rfs/hhv038 
Helmich, D. L., \& Gilroy, K. R. (2012). CEO succession and organizational transitions: Case of state-owned enterprises. Chinese Management Studies, 6(4), 568-581. doi: https://doi. org/10.1108/17506141211280263

Huson, M. R., Malatesta, P. H., \& Parrino, R. (2004). Managerial succession and firm performance. Journal of Financial Economics, 74(2), 237-275. doi: https://doi.org/10.1016/j. jfineco.2003.08.002

Jalal, A. M., \& Prezas, A. P. (2012). Outsider CEO succession and firm performance. Journal of Economics and Business, 64(6), 399-426. doi: https://doi.org/10.1016/j.jeconbus.2012.09.001

Jensen, M. C., \& Meckling, W. (1976). A theory of the firm: governance, residual claims and organizational forms. Journal of Financial Economics, 3(4), 305-360. doi: https://doi. org/10.1016/0304-405X(76)90026-X.

Jenter, D., \& Kanaan, F. (2015). CEO turnover and relative performance evaluation. Journal of Finance, 70(5), 2155-2184. doi: https://doi. org/10.1111/jofi.12282

Kothari, S. P., \& Warner, J. B. (2007). Econometrics of event studies. Handbook of Empirical Corporate Finance, 1(1), 3-36. doi: https://doi.org/10.1016/ B978-0-444-53265-7.50015-9.

Leal, R. P. C., Carvalhal, A. L., \& Iervolino, A. P. (2015). One decade of evolution of corporate governance practices in Brazil. Brazilian Review of Finance 13(1), 134-161. doi:http://dx.doi. org/10.12660/rbfin.v13n1.2015.50904

Lazzarini, S. G., \& Musacchio, A. (2015). Reinventando o Capitalismo de Estado: o Leviatã nos negócios: Brasil e outros países. São Paulo: Portfolio - Penguin.

Shen, W., \& Cannella, A. A. (2003). Will succession planning increase shareholder wealth? Evidence from investor reactions to relay CEO successions. Strategic Management Journal, 24(2), 191-198. https://doi.org/10.1002/smj.280

Silveira, A. Di M. da, \& Dias, J. A. L. (2010). What is the impact of bad governance practices in a concentrated ownership environment?. International Journal of Disclosure \& Governance, 7(1), 70-91. doi: https://doi.org/10.1057/ jdg.2009.21

Yu, S., \& Lee, N. (2016). Financial crisis, politically connected CEOs, and the performance of State-Owned enterprises: Evidence Korea. Emerging Markets Finance and Trade, 52(9), 2087-2099. doi: https://doi.org/10.1080/1540 496X.2016.1186445

Zhang, Y., \& Rajagopalan, N. (2010). Once an outsider, always an outsider? CEO origin, strategic change, and firm performance. Strategic Management Journal (John Wiley \& Sons, Inc.), 31(3), 334-346. doi: https://doi.org/10.1002/ smj. 812 


\section{Authors:}

1. Sergio Foldes Guimarães, Master in Management Science at PUC-Rio, Rio de Janeiro, Brazil.

E-mail: sergio.foldes@coppead.ufrj.br

ORCID

(iD) 0000-0001-8625-6282

2. André Luiz Carvalhal da Silva, Doctor in Management Science at Coppead/UFRJ, Rio de Janeiro, Brazil. E-mail: andrec@coppead.ufrj.br

ORCID

(iD) 0000-0003-0210-2775

\section{Contribution of each author}

\begin{tabular}{lcc}
\hline Contribution & Sergio Guimaraes & André Silva \\
\hline 1. Definition of research problem & $\sqrt{ }$ & $\sqrt{ }$ \\
2. Development of hypotheses or research questions (empirical studies) & $\sqrt{ }$ \\
3. Development of theoretical propositions (theoretical Work) & & \\
4. Theoretical foundation/ Literature review & $\sqrt{ }$ \\
5. Definition of methodological procedures & $\sqrt{ }$ \\
6. Data collection & $\sqrt{ }$ \\
7. Statistical analysis & $\sqrt{ }$ \\
8. Analysis and interpretation of data & & $\sqrt{ }$ \\
9. Critical revision of the manuscript & $\sqrt{ }$ \\
10. Manuscript Writing & & $\sqrt{ }$ \\
11. Other (please specify which) & & \\
\end{tabular}

